\title{
LTD, RP, and Motor Learning
}

$\operatorname{AUTHOR}(\mathrm{S})$ :

Hirano, Tomoo; Yamazaki, Yoshito; Nakamura, Yoji

CITATION:

Hirano, Tomoo ...[et al]. LTD, RP, and Motor Learning. Cerebellum 2016, 15(1): 51-53

ISSUE DATE:

2016-02-01

URL:

http://hdl.handle.net/2433/229519

\section{RIGHT:}

The final publication is available at Springer via https://doi.org/10.1007/s12311-015-0698-0; The full-text file will be made open to the public on 1 February 2017 in accordance with publisher's 'Terms and Conditions for Self-Archiving'.; この論文は出版社版でありません。引用の際には出版社版をご確認ご利用ください。; This is not the published version. Please cite only the published version. 
7th Symposium of SRC

\section{LTD, RP and motor learning}

Tomoo Hirano, Yoshito Yamazaki, Yoji Nakamura

Department of Biophysics, Graduate School of Science, Kyoto University, Kyoto 606-8502, Japan

Correspondence should be addressed to

T. Hirano (thirano@neurosci.biophys.kyoto-u.ac.jp) 
Conflict of interest notification

There are no potential conflicts of interest in this manuscript. 


\section{Abstract}

Long-term depression (LTD) at excitatory synapses between parallel fibers and a Purkinje cell has been regarded as a critical cellular mechanism for motor learning. However, it was demonstrated that normal motor learning occurs under LTD suppression, suggesting that cerebellar plasticity mechanisms other than LTD also contribute to motor learning. One candidate for such plasticity is rebound potentiation (RP), which is long-term potentiation at inhibitory synapses between a stellate cell and a Purkinje cell. Both LTD and RP are induced by the increase in postsynaptic $\mathrm{Ca}^{2+}$ concentration, and work to suppress the activity of a Purkinje cell. Thus, LTD and RP might work synergistically, and one might compensate defects of the other. RP induction is dependent on the interaction between $\mathrm{GABA}_{\mathrm{A}}$ receptor and $\mathrm{GABA}_{\mathrm{A}}$ receptor binding protein (GABARAP). Transgenic mice expressing a peptide which inhibits binding of GABARAP and GABA $\mathrm{A}_{\mathrm{A}}$ receptor only in Purkinje cells, show defects in both RP and adaptation of vestibulo-ocular reflex (VOR), a motor learning paradigm. However, another example of motor learning, adaptation of optokinetic response (OKR) is normal in the transgenic mice. Both VOR and OKR are reflex eye movements suppressing the slip of visual image on the retina during head movement. Previously we reported that delphilin knockout mice show facilitated LTD induction and enhanced OKR adaptation, 
but we recently found that VOR adaptation was not enhanced in the knockout mice.

These results together suggest that animals might use LTD and RP differently depending on motor learning tasks.

\section{LTD and RP}

At excitatory glutamatergic synapses between parallel fibers and a Purkinje cell, long-term depression (LTD) of glutamate responsiveness is induced by coupled activation of parallel fibers and a climbing fiber, which has been regarded as a critical cellular mechanism for motor learning [1, 2]. However, this idea has been challenged by demonstration of normal motor learning under suppression of LTD [3, 4], which suggests that plasticity mechanisms other than LTD contribute to motor learning [2, 5, 6]. Indeed, many types of synaptic plasticity have been reported in the cerebellar cortex and nuclei at various synapses such as mossy fiber-granule cell, parallel fiber-Purkinje cell, parallel fiber-stellate cell, stellate cell-Purkinje cell synapses [2]. In addition, plasticity of dendritic excitability of a Purkinje cell was reported [7]. Among them one candidate plasticity mechanism which could compensate defects of LTD, is rebound potentiation (RP) at synapses between an inhibitory stellate cell and a Purkinje cell in the molecular layer. RP is long-term potentiation of GABA responsiveness of a Purkinje 
cell induced by climbing fiber activation [8]. There are similarities between LTD and RP.

One is that both are induced by climbing fiber activity or by the increase in intracellular $\mathrm{Ca}^{2+}$ concentration in a Purkinje cell $[9,10,11]$, and the other is that both work to suppress the Purkinje cell activity. We actually found that LTD and RP were induced simultaneously by depolarizing conditioning stimulation of a rat cultured Purkinje cell, indicating that LTD and RP can be induced simultaneously in certain conditions. In addition, some intracellular signaling molecules such as mGluR1, cAMP, cGMP, CaMKII etc. are involved in both LTD and RP $[12,13]$. Therefore, some LTD-deficient mutant mice such as mGluR1 knockout mice [14] might be also defective in RP, leading to a possibility that some mutant mice show motor learning failures because of defects in both LTD and RP. On the other hand, a mutant mouse in which probably only LTD is impaired might show apparently normal motor learning [4]. However, we would like to note that there is a difference in the induction condition between LTD and RP. Not only climbing fiber activity but also parallel fiber activity is necessary for LTD induction [1], whereas only climbing fiber activity is sufficient for RP induction [8]. Thus, LTD induction is homosynaptically regulated and synapse specific, whereas RP is heterosynaptically induced and can be a cell-wide phenomenon, although there is a synapse-specific regulation mechanism for RP [15]. 


\section{RP-deficient mice}

Molecular regulation mechanisms of RP induction has been studied extensively [13], and it was revealed that interaction of $\mathrm{GABA}_{\mathrm{A}}$ receptor binding protein (GABARAP) and $\mathrm{GABA}_{\mathrm{A}}$ receptor is necessary for RP induction [16]. This result prompted us to examine physiological roles of RP using RP-deficient mice. To this end, we generated transgenic mice, in which a peptide blocking interaction of GABARAP and GABA receptor was expressed only in Purkinje cells [17]. The transgenic mice fail to show RP as expected, and have defects in adaptation of vestibulo-ocular reflex (VOR), a well-known motor learning paradigm. However, they show normal adaptation of optokinetic response (OKR), another example of motor learning. Both VOR and OKR are reflexes to stabilize the visual image on the retina during head motion. In VOR vestibular organs such as semi-circular canals detect head rotation, and drive eye balls to turn in the opposite direction of head turn reducing the blur of visual image. The timing and amplitude of VOR need to be precisely regulated so that it works adequately in daily life. Adaptation of VOR occurs when the eyeball motion fails to stabilize the visual image on the retina. For example, if rotation of a head-fixed animal is coupled with rotation of surroundings in the opposite direction or in the same direction, the gain 
of VOR increases or decreases respectively. These are gain-up and gain-down adaptation of VOR, and both are defective in RP-deficient transgenic mice. In OKR, the visual information about the relative movement of animal's surrounding drives the eyeball movement so that the latter follows the former. Often eyeball movement is too slow to follow the surrounding's movement at first. However, if movement of the visual field continues, the eye ball movement gets faster to better catch up the movement of visual field. This is adaptation of OKR, which is not affected in the RP-deficient transgenic mice. These results suggest that RP is involved in a certain type of motor learning, and that contribution of RP to motor learning might be different among tasks.

\section{Mutant mice with facilitated LTD induction}

GluD2 is an ionotropic glutamate receptor-related molecule selectively expressed in Purkinje cells and necessary for LTD induction [18, 19], and delphilin is a GluD2 binding protein which is also specifically expressed in Purkinje cells. It was previously reported that in delphilin knockout mice LTD is more easily induced than in wild-type mice and OKR adaptation is enhanced [20]. LTD is induced by a small number of conditioning depolarization coupled with parallel fiber stimulations or in the presence of a $\mathrm{Ca}^{2+}$ chelator EGTA in a delphilin knockout Purkinje cell. In these conditions a 
wild-type Purkinje cell fails to show LTD. In addition, the speed of gain increase in OKR adaptation is larger in delphilin knockout mice than in wild-type mice, suggesting that facilitation of LTD induction might contribute to enhancement of motor learning. However, we recently found that VOR adaptation was not enhanced in delphilin knockout mice compared with wild-type mice. These results together suggest that facilitated LTD might enhance OKR adaptation but not VOR adaptation. Thus, contribution of LTD to motor learning might be different among tasks as that of RP.

In summary, LTD and RP can be induced simultaneously in certain conditions, and contribution of LTD or RP to motor learning seems to be different among tasks. Thus, not only LTD but also other plastic mechanisms including RP contribute to motor learning, and that the contribution of each cerebellar plastic mechanism to motor learning is likely to be different among tasks and in various conditions.

\section{Acknowledgements}

We thank Drs. G. Ohtsuki and K. Funabiki for comments on the manuscript. This research was supported by a grant-in-aid for scientific research 25115716 in Japan to T. Hirano. 


\section{References}

[1] Ito M. Cerebellar long-term depression: characterization, signal transduction, and functional roles. Physiol Rev 2001; 81: 1143-95.

[2] Hirano T. Long-term depression and other synaptic plasticity in the cerebellum. Proc Japan Acad B 2013; 89: 183-95.

[3] Welsh JP, Yamaguchi H, Zeng XH, Kojo M, Nakada Y, Takagi A, Sugimori M, Llinás RR. Normal motor learning during pharmacological prevention of Purkinje cell long-term depression. Proc Natl Acad Sci USA 2005; 102: 17166-71.

[4] Schonewille M, Gao Z, Boele HJ, Veloz MF, Amerika WE, Simek AA, De Jeu MT, Steinberg JP, Takamiya K, Hoebeek FE, Linden DJ, Huganir RL, De Zeeuw CI. Reevaluating the role of LTD in cerebellar motor learning. Neuron 2011; 70: 43-50.

[5] Dean P, Porrill J, Ekerot CF, Jörntell H. The cerebellar microcircuit as an adaptive filter: experimental and computational evidence. Nat Rev Neurosci 2010; 11; 30-43.

[6] Gao Z, van Beugen BJ, De Zeeuw CI. Distributed synergistic plasticity and cerebellar learning. Nat Rev Neurosci 2012; 13: 619-35.

[7] Ohtsuki G, Piochon C, Adelman JP, Hansel, C. SK2 channel modulation contributes to compartment-specific dendritic plasticity in cerebellar Purkinje cells. Neuron 2012; 75: 108-20. 
[8] Kano M, Rexhausen U, Dreessen J, Konnerth A. Synaptic excitation produces a long-lasting rebound potentiation of inhibitory synaptic signals in cerebellar Purkinje cells. Nature 1992; 356: 601-04.

[9] Tanaka K, Khiroug L, Santamaria F, Doi T, Ogasawara H, Ellis-Davies G, Kawato M, Augustine GJ. $\mathrm{Ca}^{2+}$ requirements for cerebellar long-term synaptic depression: role for a postsynaptic leaky integrator. Neuron 2007; 54: 787-800.

[10] Kitagawa Y, Hirano T, Kawaguchi S. Prediction and validation of a mechanism to control the threshold for inhibitory synaptic plasticity. Mol Systems Biol 2009; 5, 280: $1-16$.

[11] Kawaguchi S, Nagasaki N, Hirano T. Dynamic impact of temporal context of $\mathrm{Ca}^{2+}$ signals on inhibitory synaptic plasticity. Sci Reports 2011; 1, 143: 1-12.

[12] Kawaguchi S, Hirano T. Gating of long-term depression by CaMKII through enhanced cGMP signaling in cerebellar Purkinje cells. J Physiol 2013; 591: 1707-30.

[13] Hirano T, Kawaguchi S. Regulation and functional roles of rebound potentiation at cerebellar stellate cell - Purkinje cell synapse. Front Cell Neurosci 2014; 8, 42: 1-8.

[14] Aiba A, Kano M, Chen C, Stanton ME, Fox GD, Herrup K, Zwingman TA, Tonegawa S. Deficient cerebellar long-term depression and impaired motor learning in mGluR1 mutant mice. Cell 1994; 7: 377-88. 
[15] Kawaguchi S, Hirano T. Suppression of inhibitory synaptic potentiation by presynaptic activity through postsynaptic $\mathrm{GABA}_{\mathrm{B}}$ receptors in a Purkinje neuron. Neuron 2000; 27: 339-47.

[16] Kawaguchi S, Hirano T. Sustained GABARAP structural change underlies long-term potentiation at inhibitory synapses on a cerebellar Purkinje neuron. $\mathrm{J}$ Neurosci 2007; 27: 6788-99.

[17] Tanaka S, Kawaguchi S, Shioi G, Hirano T. Long-term potentiation of inhibitory synaptic transmission onto cerebellar Purkinje neurons contributes to adaptation of vestibulo-ocular reflex. J Neurosci 2013; 33: 17209-20.

[18] Kashiwabuchi N, Ikeda K, Araki K, Hirano T, Shibuki K, Takayama C, Inoue Y, Kutsuwada T, Yagi T, Kang Y, Aizawa S, Mishina M. Disturbed motor coordination, Purkinje cell synapse formation and cerebellar long-term depression of mice defective in the $\delta 2$ subunit of the glutamate receptor channel. Cell 1995; 81: $245-52$.

[19] Hirano T. Cerebellar regulation mechanisms learned from studies on GluR $\delta 2$, a unique glutamate-receptor-related molecule specifically expressed at parallel fiber-Purkinje cell synapses. Mol Neurobiol 2006; 33: 1-16.

[20] Takeuchi T, Ohtsuki G, Yoshida T, Fukaya M, Wainai T, Yamashita M, Yamazaki Y, 
Mori H, Sakimura K, Kawamoto S, Watanabe M, Hirano T, Mishina M. Enhancement

of both long-term depression induction and optokinetic response adaptation in mice

lacking delphilin. PLoS One 2008; 3, e22 S97, 1-11. 